\title{
Effect of Different Wrapping Materials on Shelf Life and Quality of Papaya (Carica papaya L) cv. Taiwan Stored at Ambient Temperature
}

\author{
K.Arundathi $^{1^{*} \text {, Veena Joshi }}{ }^{2}$, M. Sreedhar ${ }^{3}$ and D. Vijaya ${ }^{4}$ \\ College of Horticulture, Sri Konda Laxman Telangana State Horticultural University, \\ Rajendranagar, Hyderabad-500 030 (Telangana), India \\ *Corresponding author
}

\section{A B S T R A C T}

Keywords

Papaya cv. Taiwan, wrapping material, Shelf life, Quality

Article Info

Accepted:

18 December 2018

Available Online:

10 January 2019
Papaya (Carica papaya L.) is economically important and a popular fruit. It is consumed as fresh fruit and vegetable and also used as also used as processed product. The present experiment was carried out during 2016-2017. The effect of different wrapping materials on shelf life and quality of papaya cv. Taiwan was investigated at ambient temperature during storage. The physical and quality characteristics such as Physiological loss in weight, Percentage of ripening, shelf life, ß-carotene, TSS, acidity, Ascorbic acid, sugars and along with organoleptic evaluation were studied at an interval of 3 days upto $12^{\text {th }}$ days after storage. The data were statistically analyzed using completely randomized design. The study shows that the Paddy straw and News paper shows high shelf life days and increased upto (11.83 days) when compared to control (5 days) and also shows highest score for organoleptic evaluation. At the end of storage studies $\mathrm{T}_{3}$ - Paddy straw stored fruits have shown the best results for TSS, Titrable acidity, Firmess, PLW (\%), ripening percentage, ascorbic acid, TSS, sugars and carotene content.

\section{Introduction}

Papaya (Carica papaya L.) is one of the most popular fruits and it is native of Tropical America belonging to family Caricaceae. It is now grown in all tropical and subtropical countries of the world due to its wide range of adaptability, high nutritive value, early returns within short period. The demand for fresh papaya fruit is increasing, due to its nutritional, medicinal and industrial value. Papaya is a very delicious, wholesome, refreshing fruit with a unique food value. The ripe fruits are used for desert purpose, preparation of jam, jelly, soft drinks, ice cream, flavoring, crystallized fruits, canned in syrup and fruits salad. The unripe fruits are consumed as vegetables which act as a contraceptive. The seeds also have medicinal properties. Papaya has a high level of post harvest loss viz. $40-100 \%$, due to its high perishable nature and thus reduces the per capita availability. Various measures have been studied to minimize the losses and one of the methods is use of wrapping materials. Packaging of fresh fruits is an integral part of post harvest handling and is one of the important step in the long and complicated journey from grower to consumer. Skin evaporation (transpiration) and to some extent 
respiration causes loss of water from fruit and this loss in weight can be effectively cut down by various packaging materials. Papaya fruits are normally transported by packaging in different wrapping materials. The packaging materials like News paper, Tissue paper, Paddy straw, shrink film wrap etc. also increases the shelf life in papaya fruits (Singh et al., 2012).

\section{Materials and Methods}

The present experiment was carried out at College of Horticulture, Sri Konda Laxman Telangana State Horticulture University, Rajendranagar, Hyderabad during the year 2016-2017.

The fruits of papaya which were physiologically mature and have attained the full size, light green with a tinge of yellow at apical end were harvested from the private orchard at Basanthpur village, $25 \mathrm{~km}$ far away from shamshabad, Rangareddy district, Telangana. The fruits were washed with water, dipped for 30 seconds in $0.01 \%$ Bavistin, dried with muslin cloth and then used for the study.

The cultivar Taiwan is a variety developed by Known-You Seed Company, 26 Change, $2^{\text {nd }}$ Road, Koshsiung, Taiwan - 802. It is early, vigorous, productive variety with long shelf life. Plants of this variety bear fruits at $80 \mathrm{~cm}$ height on the trunk and normally bear over 30 fruits per plant in each fruit setting season. It is a gynodioecious variety. Fruits are short oblong on female plants and rather long oblong shaped on bisexual plants. Flesh is thick, aromatic and red with more than 13 percent sugar. It is a good shipper and has tolerance to papaya ring spot virus.

The fruits were selected on the basis of uniformity, maturity, size and shape. The experiment was laid out in completely randomized design with 7 (Seven) treatments and 3 (replications). The treatments of the experiment comprised of different wrapping materials, $\mathrm{T}_{1}-$ News paper, $\mathrm{T}_{2}$ - Tissue paper, $\mathrm{T}_{3^{-}}$Paddy straw, $\mathrm{T}_{4}-$ Shrink film, $\mathrm{T}_{5^{-}}$Foam nets, $\mathrm{T}_{6^{-}} \mathrm{CFB}$ (Corrugated Fiber Board) and $\mathrm{T}_{7}$ - Control. Each treatment had 12 fruits and sampled 3,6,9 and $12^{\text {th }}$ days after storage. The nine fruits sampled were assessed for TSS, titrable acidity, Ascorbic acid, B-carotene, sugars and remaining three fruits were used to assess the percentage of ripening and weight loss.

\section{Results and Discussion}

\section{Physiological loss in weight}

The results indicated that the effect of wrapping materials on weight loss as significantly different at various levels of storage (Table 1). The minimum weight loss was observed in $\mathrm{T}_{4}$-Shrink film i.e., (6.9) followed by $\mathrm{T}_{2^{-}}$Tissue paper i.e., (7.87) and the maximum PLW was recorded by $\mathrm{T}_{1}-$ Newspaper (8.36) after twelfth days of storage.

The reduced weight loss may be possible due to slow rate of transpiration caused by wrapping material because they reduce the temperature between outer and inner atmosphere. Reduction in the rate of transpiration is suggested to be one of the major criteria for extending the post harvest life of fruits. The weight loss in shrink wrapped pomegranates fruits was $1.2 \%-1.3 \%$ after 12 weeks of storage at $8^{\circ} \mathrm{C}$ and $2.2-3.7 \%$ after 10 weeks at $15^{\circ} \mathrm{C}$. In Anab-e-Shahi grapes, Bhullar et al., (1980) reported that the physiological loss in weight of grapes was minimum by polythene wrappers compared to paper wrapper. The results obtained in the present investigation are in close conformity with those of Singh et al., (2012) in papaya fruits. 


\section{Percentage of ripening $(\%)$}

The data show (Table 2) that papaya fruits on effect of different wrapping materials on Percentage of ripening (\%) of papaya cv. Taiwan There were significant differences observed among different treatments with respect to ripening, The minimum ripening percentage was observed in $\mathrm{T}_{3}$-Paddy straw (41.15) followed by $\mathrm{T}_{1}$-News paper i.e., (43.11) and the maximum ripening was recorded by $\mathrm{T}_{7}$ i.e. (51.81) in control fruits after $12^{\text {th }}$ day of storage.

\section{Shelf life (days)}

The effect of different wrapping materials on shelf life (days) of papaya cv. Taiwan is presented in the (Table 3). The treated fruits differed significantly with highest shelf life (11.83) recorded in fruits wrapped with $\mathrm{T}_{3^{-}}$ Paddy straw followed by $\mathrm{T}_{1^{-}}$News paper (11.29)wrapped fruits. The lowest shelf life was recorded in $\mathrm{T}_{7}$ - control (7.31). The fruits wrapped with T5- Foam nets (9.15) has lower shelf life than the other wrapping material fruits treatments.

\section{ß-Carotene (mg/100g)}

The effect of different wrapping materials on $\beta$-Carotene $(\mathrm{mg} / 100 \mathrm{~g})$ of papaya $\mathrm{cv}$. Taiwan stored at ambient temperature $\left(25 \pm 1^{\circ} \mathrm{C}\right)$ is presented in the Table 4 indicate that there were significant changes in $\beta$-Carotene content during the storage period, by the treatments. B-Carotene increased upto the interval of 9 days after storage and decreased later. Maximum carotene was observed in $\mathrm{T}_{3^{-}}$ Paddy straw (0.57) followed by $\mathrm{T}_{1^{-}}$News paper $(0.51)$ treated fruits and the lowest $\beta$ Carotene was recorded by $T_{7}$ (0.32) in control fruits. The carotenoids increased in early days of storage and declined in all the treatments. The carotene content in ripe papaya is higher than over ripe papaya. However, higher carotenoids were recorded in newspaper and paddystraw stored fruits. Similar results were taken up by Singh et al., (2012) in papaya fruits.

\section{Ascorbic acid (mg/100g)}

Ascorbic acid has increased upto 9 days of storage in the treatments of $T_{1}, T_{2}, T_{3}, T_{4}, T_{5}$, $T_{6}$ and $T_{7}$ The data pertaining to the effect of different wrapping materials on Ascorbic acid $(\mathrm{mg} / 100 \mathrm{~g})$ of papaya cv. Taiwan was significant over control. The highest ascorbic acid was observed in $\mathrm{T}_{3}$-Paddy straw (52.91) followed by $\mathrm{T}_{1}$-News paper (49.21) wrapped fruits and the lowest ascorbic acid was recorded in $\mathrm{T}_{7}$-control (34.3). The higher ascorbic acid was recorded in the fruits wrapped in paddy straw and news paper compared to any other treatments. Similar result was reported by Alam et al., (2010) in papaya fruits (Table 5).

\section{Total soluble solids $\left({ }^{\circ} \mathrm{B}\right)$}

The effect of different wrapping materials on TSS ( ${ }^{\circ}$ Brix) of papaya cv. Taiwan stored at ambient temperature $\left(25 \pm 1^{\circ} \mathrm{C}\right)$ was presented in the Table 6 . There were significant differences in TSS among different days of storage period. The highest TSS was observed in $T_{3}$-Paddy straw (12.18) and followed by $\mathrm{T}_{1}$ - News paper (12.09) wrapped fruits and the lowest TSS was recorded in $\mathrm{T}_{7}-$ control (4.82).

Sandho and Singh (1983) have reported that the highest TSS under Paddy straw in peaches. The results of papaya TSS were similar to results obtained by Singh et al., (2012) in papaya fruits.

\section{Titrable acidity (\%)}

The data pertaining to titrable acidity (\%) of papaya cv. Taiwan was presented in the Table 7. 
Table.1 Effect of wrapping materials on Physiological loss in weight (PLW) (\%) of papaya cv. Taiwan stored at ambient temperature

\begin{tabular}{|c|c|c|c|c|c|}
\hline \multirow[t]{3}{*}{ Treatment } & \multicolumn{5}{|c|}{ PLW (\%) } \\
\hline & \multicolumn{5}{|c|}{ Days after Storage } \\
\hline & 3 & 6 & 9 & 12 & Mean \\
\hline $\mathbf{T}_{1}$ & 3.60 & 7.54 & 10.19 & 12.09 & 8.36 \\
\hline $\mathbf{T}_{2}$ & 4.08 & 8.23 & 11.30 & $*$ & 7.87 \\
\hline $\mathbf{T}_{\mathbf{3}}$ & 3.08 & 7.12 & 9.85 & 11.97 & 8.01 \\
\hline $\mathbf{T}_{4}$ & 2.83 & 7.57 & 10.29 & $*$ & 6.9 \\
\hline $\mathbf{T}_{5}$ & 4.58 & 8.63 & 11.67 & $*$ & 8.29 \\
\hline $\mathbf{T}_{6}$ & 4.48 & 8.42 & 11.39 & $*$ & 8.1 \\
\hline $\mathbf{T}_{7}$ & 5.17 & 9.21 & $*$ & $*$ & 7.19 \\
\hline \multirow[t]{2}{*}{ Mean } & 3.97 & 8.10 & 10.78 & \multirow[t]{2}{*}{12.03} & \\
\hline & 3 & \multicolumn{2}{|c|}{6} & & 12 \\
\hline SE(m) & 0.22 & \multicolumn{2}{|c|}{013} & 0.12 & 0.13 \\
\hline CD at $5 \%$ & 0.66 & \multicolumn{2}{|c|}{0.40} & 0.39 & 0.42 \\
\hline
\end{tabular}

*- End of shelf life.

\section{Treatments:}

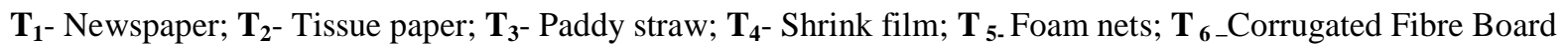
(CFB); $\mathbf{T}_{7-}$ Control (Without wrapping).

Table.2 Effect of wrapping materials on percentage of ripening (\%) of papaya cv. Taiwan stored at ambient temperature

\begin{tabular}{|c|c|c|c|c|c|}
\hline \multirow{2}{*}{ Treatments } & \multicolumn{5}{|c|}{ Percentage of ripening (\%) } \\
\cline { 2 - 6 } & $\mathbf{3}$ & $\mathbf{6}$ & $\mathbf{9}$ & $\mathbf{1 2}$ & Mean \\
\hline $\mathbf{T}_{\mathbf{1}}$ & 28.34 & 35.84 & 49.63 & 58.64 & 43.11 \\
\hline $\mathbf{T}_{\mathbf{2}}$ & 34.34 & 47.40 & 56.30 & $*$ & 46.01 \\
\hline $\mathbf{T}_{\mathbf{3}}$ & 25.31 & 33.53 & 48.64 & 57.11 & 41.15 \\
\hline $\mathbf{T}_{\mathbf{4}}$ & 32.51 & 45.32 & 57.50 & $*$ & 45.11 \\
\hline $\mathbf{T}_{\mathbf{5}}$ & 36.20 & 48.10 & 59.60 & $*$ & 47.97 \\
\hline $\mathbf{T}_{\mathbf{6}}$ & 35.32 & 46.20 & 55.64 & $*$ & 45.72 \\
\hline $\mathbf{T}_{\mathbf{7}}$ & 45.31 & 58.31 & $*$ & $*$ & 51.81 \\
\hline Mean & 33.90 & 44.96 & 54.55 & 57.88 & \\
\hline $\mathbf{S E}(\mathbf{m})$ & $\mathbf{3}$ & $\mathbf{6}$ & $\mathbf{9}$ & \multicolumn{2}{|c|}{$\mathbf{1 2}$} \\
\hline CD at 5\% & 0.003 & 0.03 & 0.003 & \multicolumn{2}{|c|}{0.002} \\
\hline
\end{tabular}

* - End of shelf life.

\section{Treatments:}

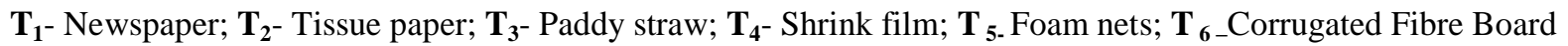
(CFB); $\mathbf{T}_{7-}$ Control (Without wrapping). 
Table.3 Effect of wrapping materials on shelf life (days) of papaya cv. Taiwan stored at ambient temperature

\begin{tabular}{|c|c|}
\hline Treatments & Shelf life (days) \\
\hline & $\mathbf{T}_{\mathbf{1}}$ \\
\hline $\mathbf{T}_{\mathbf{2}}$ & 11.29 \\
\hline $\mathbf{T}_{\mathbf{3}}$ & 9.42 \\
\hline $\mathbf{T}_{\mathbf{4}}$ & 11.83 \\
\hline $\mathbf{T}_{\mathbf{5}}$ & 9.61 \\
\hline $\mathbf{T}_{\mathbf{6}}$ & 9.15 \\
\hline $\mathbf{T}_{\mathbf{7}}(\mathbf{C o n t r o l})$ & 9.34 \\
\hline Mean & 7.31 \\
\hline SE(m) & 9.70 \\
\hline CD at 5\% & 0.02 \\
\hline
\end{tabular}

\section{Treatments:}

$\mathbf{T}_{1^{-}}$Newspaper; $\mathbf{T}_{2^{-}}$Tissue paper; $\mathbf{T}_{3^{-}}$Paddy straw; $\mathbf{T}_{4^{-}}$Shrink film; $\mathbf{T}_{5 \text { - }}$ Foam nets; $\mathbf{T}_{6}$ _Corrugated Fibre Board (CFB); $\mathbf{T}_{7-}$ Control (Without wrapping).

Table.4 Effect of wrapping materials on $ß$-Carotene $(\mathrm{mg} / 100 \mathrm{~g})$ of papaya cv. Taiwan stored at ambient temperature

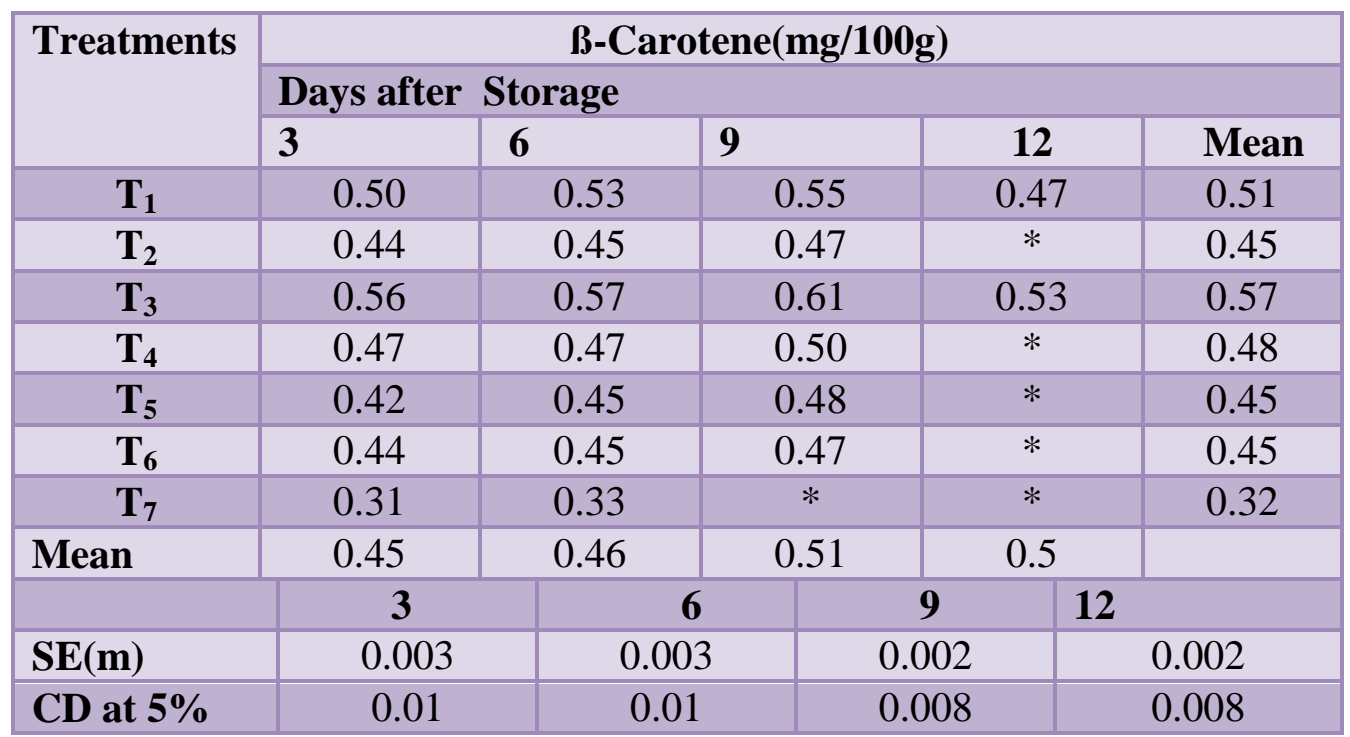

*- End of shelf life.

\section{Treatments:}

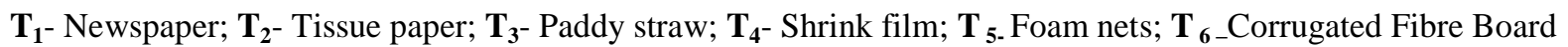
(CFB); $\mathbf{T}_{7-}$ Control (Without wrapping). 
Table.5 Effect of wrapping materials on Ascorbic acid $(\mathrm{mg} / 100 \mathrm{~g})$ of papaya cv. Taiwan stored at ambient temperature

\begin{tabular}{|c|c|c|c|c|c|c|}
\hline \multirow[t]{3}{*}{ Treatments } & \multicolumn{6}{|c|}{ Ascorbic acid (mg/100g) } \\
\hline & \multicolumn{6}{|c|}{ Days after Storage } \\
\hline & 3 & 6 & 9 & \multicolumn{2}{|c|}{12} & Mean \\
\hline $\mathbf{T}_{1}$ & 32.22 & 50.70 & 63.52 & \multicolumn{2}{|c|}{50.4} & 49.21 \\
\hline $\mathbf{T}_{2}$ & 28.16 & 44.14 & 48.16 & \multicolumn{2}{|c|}{$*$} & 40.15 \\
\hline $\mathbf{T}_{3}$ & 34.41 & 54.46 & 67.12 & \multicolumn{2}{|c|}{55.63} & 52.91 \\
\hline $\mathbf{T}_{4}$ & 29.38 & 45.55 & 57.23 & \multicolumn{2}{|c|}{$*$} & 44.05 \\
\hline $\mathbf{T}_{5}$ & 27.51 & 43.00 & 55.67 & \multicolumn{2}{|c|}{$*$} & 42.06 \\
\hline $\mathbf{T}_{6}$ & 27.43 & 43.30 & 58.42 & \multicolumn{2}{|c|}{$*$} & 43.05 \\
\hline $\mathbf{T}_{7}$ & 27.12 & 41.47 & $*$ & \multicolumn{2}{|c|}{$*$} & 34.3 \\
\hline \multirow[t]{2}{*}{ Mean } & 29.46 & 46.09 & 58.35 & \multicolumn{2}{|c|}{53.02} & \\
\hline & \multicolumn{2}{|l|}{3} & 6 & \multicolumn{2}{|r|}{1} & \\
\hline SE(m) & 0.33 & \multicolumn{2}{|c|}{0.36} & \multicolumn{2}{|c|}{0.24} & 0.13 \\
\hline CD at $5 \%$ & 1.01 & \multicolumn{2}{|c|}{1.11} & \multicolumn{2}{|c|}{0.73} & 0.41 \\
\hline
\end{tabular}

*- End of shelf life.

Treatments:

$\mathbf{T}_{\mathbf{1}^{-}}$Newspaper; $\mathbf{T}_{\mathbf{2}^{-}}$Tissue paper; $\mathbf{T}_{\mathbf{3}^{-}}$Paddy straw; $\mathbf{T}_{\mathbf{4}^{-}}$Shrink film; $\mathbf{T}_{\mathbf{5}}$. Foam nets; $\mathbf{T}_{\mathbf{6}}$-Corrugated Fibre Board (CFB); $\mathbf{T}_{7-}$ Control (Without wrapping).

Table.6 Effect of wrapping materials on TSS $\left({ }^{\circ} \mathrm{B}\right)$ of papaya cv. Taiwan stored at ambient temperature

\begin{tabular}{|c|c|c|c|c|c|c|}
\hline \multirow{3}{*}{ Treatments } & \multicolumn{6}{|c|}{ TSS $\left({ }^{\circ} \mathbf{B}\right)$} \\
\hline & \multicolumn{6}{|c|}{ Days after Storage } \\
\hline & 3 & 6 & \multirow{2}{*}{$\begin{array}{c}9 \\
15.34\end{array}$} & \multicolumn{2}{|c|}{12} & Mean \\
\hline $\mathbf{T}_{1}$ & 7.33 & 12.42 & & \multicolumn{2}{|c|}{13.27} & 12.09 \\
\hline $\mathbf{T}_{2}$ & 7.23 & 12.27 & 15.27 & \multicolumn{2}{|c|}{$*$} & 8.69 \\
\hline $\mathbf{T}_{\mathbf{3}}$ & 7.43 & 12.46 & 15.43 & \multicolumn{2}{|c|}{13.41} & 12.18 \\
\hline $\mathbf{T}_{4}$ & 6.84 & 6.87 & 9.50 & \multicolumn{2}{|c|}{$*$} & 5.80 \\
\hline $\mathbf{T}_{5}$ & 7.18 & 12.23 & 15.10 & \multicolumn{2}{|c|}{$*$} & 8.63 \\
\hline $\mathbf{T}_{6}$ & 7.21 & 12.32 & 15.23 & \multicolumn{2}{|c|}{$*$} & 8.69 \\
\hline $\mathbf{T}_{7}$ & 7.19 & 12.07 & $*$ & \multicolumn{2}{|c|}{$*$} & 4.82 \\
\hline \multirow[t]{2}{*}{ Mean } & 7.20 & 11.52 & 12.27 & \multicolumn{2}{|c|}{3.81} & \\
\hline & 3 & \multicolumn{2}{|c|}{6} & & \multicolumn{2}{|c|}{12} \\
\hline SE(m) & 0.003 & \multicolumn{2}{|c|}{0.003} & & \multicolumn{2}{|r|}{0.002} \\
\hline CD at $5 \%$ & 0.01 & \multicolumn{2}{|c|}{0.01} & & \multicolumn{2}{|r|}{0.005} \\
\hline
\end{tabular}

*- End of shelf life

Treatments:

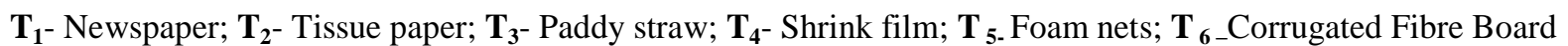
(CFB); $\mathbf{T}_{7_{-}}$Control (Without wrapping). 
Table.7 Effect of wrapping materials on Titrable acidity (\%) of papaya cv. Taiwan stored at ambient temperature

\begin{tabular}{|c|c|c|c|c|c|}
\hline \multirow{3}{*}{ Treatments } & \multicolumn{5}{|c|}{ Titrable acidity (\%) } \\
\hline & \multicolumn{5}{|c|}{ Days after Storage } \\
\hline & 3 & 6 & 9 & 12 & Mean \\
\hline$T_{1}$ & 0.23 & 0.15 & 0.12 & 0.09 & 0.15 \\
\hline $\mathbf{T}_{2}$ & 0.25 & 0.17 & 0.14 & $*$ & 0.14 \\
\hline $\mathbf{T}_{3}$ & 0.22 & 0.14 & 0.11 & 0.08 & 0.14 \\
\hline $\mathbf{T}_{4}$ & 0.27 & 0.20 & 0.16 & $*$ & 0.16 \\
\hline$T_{5}$ & 0.30 & 0.21 & 0.18 & * & 0.17 \\
\hline$T_{6}$ & 0.28 & 0.20 & 0.17 & $*$ & 0.16 \\
\hline $\mathbf{T}_{7}$ & 0.31 & 0.21 & * & * & 0.13 \\
\hline \multirow[t]{2}{*}{ Mean } & 0.27 & 0.18 & 0.13 & 0.02 & \\
\hline & 3 & \multicolumn{2}{|c|}{6} & 9 & 12 \\
\hline SE(m) & 0.03 & \multicolumn{2}{|c|}{0.003} & 0.003 & 0.002 \\
\hline CD at $5 \%$ & 0.01 & \multicolumn{2}{|c|}{0.01} & & 0.005 \\
\hline
\end{tabular}

*- End of shelf life

Treatments:

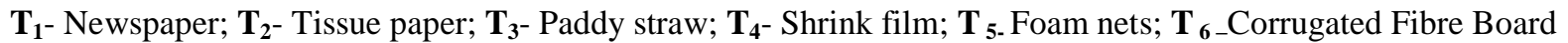
(CFB); $\mathbf{T}_{7_{-}}$Control (Without wrapping).

Table.8 Effect of wrapping materials on Reducing sugars (\%) of papaya cv. Taiwan stored at ambient temperature

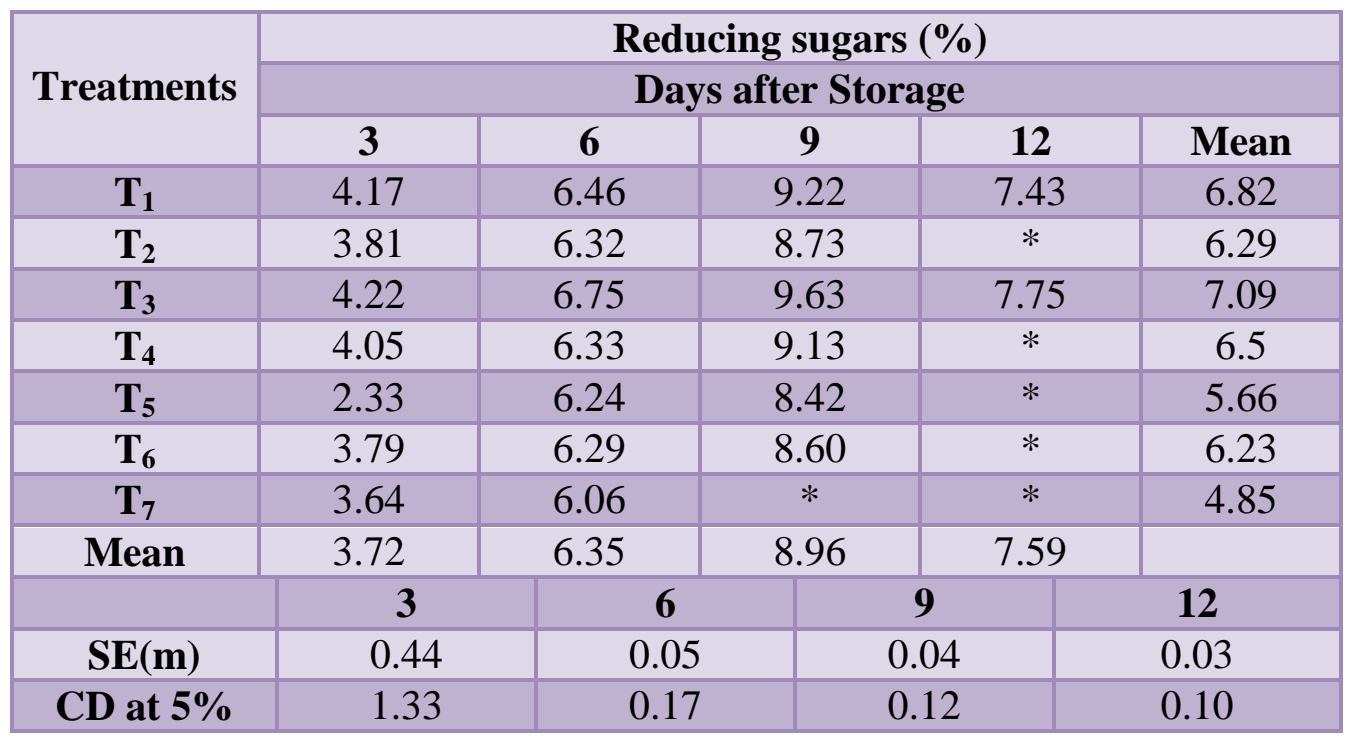

*- End of shelf life.

\section{Treatments:}

$\mathbf{T}_{\mathbf{1}^{-}}$Newspaper; $\mathbf{T}_{\mathbf{2}^{-}}$Tissue paper; $\mathbf{T}_{\mathbf{3}^{-}}$Paddy straw; $\mathbf{T}_{\mathbf{4}^{-}}$Shrink film; $\mathbf{T}_{\mathbf{5}}$. Foam nets; $\mathbf{T}_{\mathbf{6}}$-Corrugated Fibre Board (CFB); $\mathbf{T}_{7_{-}}$Control (Without wrapping). 
Table.9 Effect of wrapping materials on Total sugars (\%) of papaya cv. Taiwan stored at ambient temperature

\begin{tabular}{|c|c|c|c|c|c|}
\hline \multirow{3}{*}{ Treatments } & \multicolumn{5}{|c|}{ Total sugars (\%) } \\
\hline & \multicolumn{5}{|c|}{ Days after Storage } \\
\hline & 3 & 6 & 9 & 12 & Mean \\
\hline $\mathbf{T}_{1}$ & 5.51 & 9.08 & 11.21 & 9.38 & 8.8 \\
\hline $\mathbf{T}_{2}$ & 5.25 & 8.62 & 10.15 & $*$ & 8.01 \\
\hline $\mathbf{T}_{3}$ & 5.81 & 9.19 & 11.66 & 9.81 & 9.12 \\
\hline $\mathbf{T}_{4}$ & 5.34 & 8.77 & 10.32 & $*$ & 8.14 \\
\hline $\mathbf{T}_{5}$ & 5.10 & 8.37 & 10.09 & $*$ & 7.85 \\
\hline $\mathbf{T}_{6}$ & 5.13 & 8.52 & 10.10 & $*$ & 7.92 \\
\hline $\mathbf{T}_{7}$ & 4.89 & 8.17 & $*$ & $*$ & 6.53 \\
\hline \multirow[t]{2}{*}{ Mean } & 5.29 & 8.67 & 10.59 & 9.6 & \multirow[b]{2}{*}{12} \\
\hline & 3 & \multicolumn{2}{|c|}{6} & & \\
\hline SE(m) & 0.02 & \multicolumn{2}{|c|}{0.02} & & 0.01 \\
\hline CD at $5 \%$ & 0.07 & \multicolumn{2}{|c|}{0.07} & & 0.05 \\
\hline
\end{tabular}

*- End of shelf life.

Treatments:

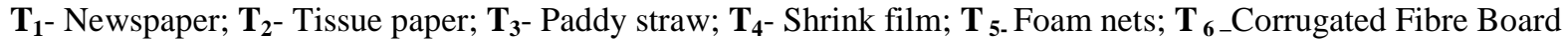
(CFB); $\mathbf{T}_{7-}$ Control (Without wrapping).

Table.10 Effect of wrapping materials on organoleptic evaluation (Score) of papaya cv. Taiwan stored at ambient temperature

\begin{tabular}{|c|c|c|c|c|c|}
\hline & \multicolumn{5}{|c|}{ Organoleptic evaluation (Score) } \\
\cline { 2 - 6 } Treatments & $\begin{array}{c}\text { Colour and } \\
\text { appearance }\end{array}$ & Texture & Taste & Flavour & $\begin{array}{l}\text { Overall } \\
\text { acceptability }\end{array}$ \\
\hline $\mathbf{T}_{\mathbf{1}}$ & 3.72 & 3.73 & 3.45 & 3.52 & 4.26 \\
\hline $\mathbf{T}_{\mathbf{2}}$ & 3.40 & 3.32 & 3.23 & 3.30 & 3.55 \\
\hline $\mathbf{T}_{\mathbf{3}}$ & 4.71 & 4.49 & 4.27 & 4.53 & 4.99 \\
\hline $\mathbf{T}_{\mathbf{4}}$ & 3.62 & 3.51 & 3.35 & 3.46 & 4.12 \\
\hline $\mathbf{T}_{\mathbf{5}}$ & 3.21 & 3.28 & 3.22 & 3.32 & 3.25 \\
\hline $\mathbf{T}_{\mathbf{6}}$ & 3.29 & 3.29 & 3.28 & 3.42 & 3.28 \\
\hline $\mathbf{T}_{\mathbf{7}}(\mathbf{C o n t r o l})$ & 3.02 & 3.02 & 2.93 & 3.10 & 3.21 \\
\hline Mean & 3.57 & 3.52 & 3.39 & 3.52 & 3.81 \\
\hline SE(m) & 0.03 & 0.01 & 0.02 & 0.02 & 0.01 \\
\hline CD at 5\% & 0.09 & 0.04 & 0.09 & 0.06 & 0.05 \\
\hline
\end{tabular}

\section{Description}

Highly acceptable

Acceptable

Fairly acceptable

Poorly acceptable

Not acceptable

\section{Score}

5

4

3

2

1


The titrable acidity in the fruits was significantly affected by the duration, the treatments and their interactions. The lowest levels of acidity was observed in $\mathrm{T}_{3}$ - Paddy straw (0.14) and $\mathrm{T}_{2^{-}}$Tissue paper(0.14) wrapped fruits and the highest acidity was recorded by $\mathrm{T}_{6}$ - Foam nets (0.17) .

A decrease in acidity during ripening and storage could be attributed to the use of organic acids as respiratory substrate (Echeverria and Valich 1989). In shrink wrapped fruits the lowering of acidity was delayed which might be due to the effect of shrink packaging film in delaying the respiratory and ripening process (Mahajan et al 2013). Results of papaya TA were similar to results obtained by Mahajan et al., (2014) in Kinnow fruits.

\section{Sugars $(\%)$}

The effect of different wrapping materials on Reducing sugars (\%) and Total sugars of papaya $\mathrm{cv}$. Taiwan stored, which indicates that there were significant changes in reducing sugars and total sugars among the treatments. Total sugars and reducing sugars showed a progressive increasing trend upto 9 days after storage (Table 8 and 9). Thereafter decline in Total sugars and reducing sugars was observed. The fruits wrapped with $\mathrm{T}_{3^{-}}$ Paddy straw (7.09) shows highest and the lowest was recorded in $\mathrm{T}_{7}$-Control (4.85) in Reducing sugars.

The fruits wrapped with $\mathrm{T}_{3^{-}}$Paddy straw (9.12) shows highest total sugars content and followed by $\mathrm{T}_{1}$-News paper (8.8) wrapped fruits and the lowest was recorded in $\mathrm{T}_{7}-$ control (6.53) in total sugars.

A comparatively lesser increase in total sugars, Reducing and Non-reducing sugars of paddy straw wrapped fruits after 9 days of storage as compared to others. The increase in sugars during storage may possibly be due to breakdown of complex organic metabolites into sugars. The decline in the sugars content at the later stages of storage may be attributed to the reason after the completion of hydrolysis of starch, no further increase in sugars occurred and subsequently a decline in these parameters is predictable as they along with organic acids are primary for respiration. The results of Sugars were similar to results obtained by Singh et al., (2012) in papaya fruits.

\section{Organoleptic evaluation}

The results of organoleptic evaluation of papaya cv. Taiwan including colour and appearance, texture, taste, flavour and overall acceptability are presented in the Table 10 . $\mathrm{T}_{4^{-}}$- 0.8kGy treated fruits showed a gradual and steady increase in the organoleptic evaluation upto 12 days of storage. There is a significant difference among all the treatments. With respect to the colour and appearance, texture, taste and flavour and overall acceptability of fruits, recorded highest score in $\mathrm{T}_{3}$ - Paddy straw (4.99) and followed by $\mathrm{T}_{1}$-News paper (4.26) wrapped fruits and the lowest score was observed in $\mathrm{T}_{7^{-}}$control (3.21) fruits and followed by $\mathrm{T}_{5^{-}}$ Foam nets (3.25).

Papaya flavor depends on a delicate balance of sugars, acids and aromatic compounds, with a number of additional factors such as pulp texture and visual appearance also influence the perceived quality and consumer acceptance and appreciation. The shrink film delayed the loss of green color in papaya fruits. The improvement in color during storage might be due to degradation of the chlorophyll pigments of the fruits and increased synthesis of carotenoids. Paddystraw ripened fruits have shown the 
best results in terms of color, flavor, texture, taste and overall acceptability on ripening after 6 days of storage. Same results were observed in papaya fruits by Singh et al., (2012).

It may be concluded that the treatment of $\mathrm{T}_{3^{-}}$ Paddy straw wrapped fruits can be useful for retaining the quality of papaya fruits for 11 day storage while shrink film delayed the ripeneing process and most promisingly among the wrapping material under study and gives high shelf life and storage quality of fruits by observing different parameters and highest score for organoleptic evaluation.

\section{References}

Alam M. S., M. M. Hossain, Amanullah, M. I. Ara and M. F. Mondal. 2010. Effect of packaging materials and growth regulators on quality and shelf life of papaya. Bangladesh Research Publication Journal. 3: 1052-1061.

Bhullar J. S., B. S. Dhillion and J. S. Randhava. 1980. Effect of wrapper on the storage of Anab-e-grapes, India Food Packaging. 34: 24-26.
Echeverria E and Valich J 1989. Enzymes of sugar and acid metabolism in stored Valencia oranges. Journal of the American Society for Horticultural Science.114: 445-449.

Mahajan, B and Rupinder, S.2014.Effect of packaging films on shelf life and quality of kinnow fruits packed in consumer packages. International Journal of Farm Sciences. 4 (1):92-98.

Mahajan, B.V. C. Dhillon, W. S. Mahesh, K. and Bikramjit, S.2015. Effect of different packaging films on shelf life and quality of peach under super and ordinary market conditions. Journal of Food Science and Technology. 52 (6):3756-3762.

Sandho A. S. And Z. Singh. 1983. Effect of ethephon on maturation and fruit quality of peach. Journal of Punjab Horticulture. 23: 172-175.

Singh, P. Sanjay, K and Satanu, M.2012. Effect of different wrapping materials on post harvest changes in papaya (Carica papaya). Environment \& Ecology. 30 (3A): 773-777.

\section{How to cite this article:}

Arundathi, K., Veena Joshi, M. Sreedhar and Vijaya, D. 2019. Effect of Different Wrapping Materials on Shelf Life and Quality of Papaya (Carica papaya L) cv. Taiwan Stored at Ambient Temperature. Int.J.Curr.Microbiol.App.Sci. 8(01): 2543-2552.

doi: https://doi.org/10.20546/ijcmas.2019.801.267 